\title{
Mycoparasitism of Endophytic Fungi Isolated From Reed on Soilborne Phytopathogenic Fungi and Production of Cell Wall-Degrading Enzymes In Vitro
}

\author{
Ronghua Cao $\cdot$ Xiaoguang Liu $\cdot$ Kexiang Gao $\cdot$ \\ Kurt Mendgen $\cdot$ Zhensheng Kang $\cdot$ Jianfeng Gao • \\ Yang Dai $\cdot$ Xue Wang
}

\begin{abstract}
Antagonism of three endophytic fungi isolated from common reed (Phragmites australis) against eight soilborne pathogenic fungi was investigated on potato dextrose agar by light microscopy, scanning electron microscopy, and transmission electron microscopy. Inhibitory zones were not observed. The microscopical studies suggested that the endophytes inhibit growth of soilborne pathogens by means of coiling around hyphae and, after penetration, the degradation of hyphal cytoplasm. Since penetration of hyphae seems to play a major role in parasitism, we studied the production of cell wall degrading enzymes by the three endophytes. Choiromyces aboriginum produced higher activities of $\beta$-1,3-glucanases compared to Stachybotrys elegans and Cylindrocarpon sp. For C. aboriginum and $S$. elegans, colloidal chitin was the best substrate for the induction of $\beta$-1,3-glucanases and chitinases, respectively. This result suggests that mycoparasitism by
\end{abstract}

R. Cao $\cdot$ K. Gao $(\bowtie) \cdot$ J. Gao $\cdot$ Y. Dai $\cdot$ X. Wang Department of Plant Pathology, Shandong Agricultural University, Taian 271018, People's Republic of China e mail: kexianggao@yahoo.com

X. Liu

Institute of Life Sciences, Jiangsu University, Zhenjiang 212013,

People's Republic of China

K. Mendgen $(\square)$

Department of Biology, University of Constance,

78457 Constance, Germany

e mail: kurt.w.mendgen@uni konstanz.de

\section{Z. Kang}

Key Laboratory of Molecular Biology for Agriculture, Shaanxi Province, Northwest A \& F University, Yangling 712100,

People's Republic of China endophytes on soilborne plant pathogens can be explained by their mycoparasitic activity.

\section{Introduction}

Root rot disease, caused by soilborne pathogenic fungi including Pythium spp., Rhizoctonia spp., and Fusarium spp. cause widespread, serious economic loss both in greenhouse and field production systems under conditions favorable for disease development. Several studies have shown that some biological control agents (BCAs) such as Trichoderma spp. can reduce the incidence of root diseases caused by soilborne pathogenic fungi [33]. BCAs inhibit plant pathogens through one or more of the following mechanisms: mycoparasitism, competition for key nutrients and colonization sites, production of antibiotics, or stimulation of plant defense mechanisms [37]. Many mycoparasites such as Chaetomium globosum [21], Chaetomium spirale [16, 17], Pythium oligandrum [32], Fusarium oxyporum strain Fo47 [4], Candida saitoana [13], and Verticilium lecanii [2] have been documented since Weinding (1932) observed mycoparasitism of Trichoderma spp. [38].

Mycoparasites produce cell wall degrading enzymes (CWDEs) which allow them to bore holes into other fungi and extract nutrients for their own growth. Most phytopathogenic fungi have a cell wall with chitin as a structural backbone arranged in regularly ordered layers and $\beta-1,3-$ glucans as a filling material arranged in an amorphous manner [10]. Chitinases and $\beta$-1,3-glucanases have been found to be involved in the parasitic interaction between Trichoderma species and its hosts [24]. Therefore, a study of CWDEs from mycoparasites is very essential for the evaluation of the biocontrol potential of BCAs. 
Endophytic fungi Choiromyces aboriginum (isolate Mü1W1C6), Stachybotrys elegans (isolate Mt2W1C1), and Cylindrocarpon sp. (isolate 5/97-12, Mt2W3C4) have been isolated from common reed (Phragmites australis) in the littoral of Lake Constance (Germany) [31]. Preliminary tests suggested antagonism against several soilborne fungal pathogens. Previous studies have already demonstrated that $S$. elegans isolated from soil can be a rich source of glucanolytic, chitinolytic, proteolytic, and cellulolytic enzymes [1, 35, 36]. It is capable of releasing $\beta$-1,3-glucanases and chitinases into a culture medium previously amended with Rhizoctonia solani cell wall fragments or chitin as a carbon source [35] which degrade $R$. solani cell walls [5, 6]. However, little is known about the mechanisms effective during the antagonism against soilborne pathogenic fungi and a possible production of hydrolytic enzymes by $C$. aboriginum, Cylindrocarpon sp., and $S$. elegans isolated from common reed.

In order to use these endophytic fungi as BCAs to control root rot diseases in the greenhouse and field, their mode of action should be studied. The main objectives of this study were to analyze the antagonisms of the three endophytic fungi $C$. aboriginum, S. elegans, and Cylindrocarpon sp. against soilborne phytopathogenic fungi and to determine which characters may contribute to their biological activities.

\section{Materials and Methods}

\section{Fungal and Plant Material}

The endophytic fungi Choiromyces aboriginum isolate Mü1W1C6, Stachybotrys elegans isolate Mt2W1C1, and Cylindrocarpon sp. isolate 5/97-12, Mt2W3C4 were isolated from roots of common reed ( $P$. australis) in the littoral of Lake Constance (Germany). Details concerning the location and the molecular characterization have been published previously [31, 39].

The soilborne pathogenic fungi Fusarium graminearum isolated from wheat (Triticum aestivum L.), F. oxysporum f. sp. perniciosum isolated from albizzia (Albizzia julibrissin Durazz.), F. oxysporum f. sp. vasinfectum isolated from cotton (Gossypium hirsutum L.), Gaeumanomyces graminis var. tritici isolated from wheat (Triticum aestivum L.), Pythium aphanidermatum isolated from cucumber (Cucumis sativus L.), Rhizoctonia cerealis isolated from wheat (Triticum aestivum L.), R. solani isolated from seedlings of pine (Pinus tabulaeformis Carrb.), and Sclerotium rolfsii isolated from whitethorn (Crataegus pinnatifida Bunge) are preserved in the Lab for Resource Microorganism, Department of Plant Pathology of Shandong Agricultural University in People's Republic of
China. All fungi were cultured on potato dextrose agar (PDA) plates.

Antagonism Tests In Vitro

\section{Growth of Pathogenic Fungi in Dual Cultures}

Petri dishes $(60 \mathrm{~mm})$ containing $6 \mathrm{ml}$ of sterile PDA were inoculated with a $5 \mathrm{~mm}$ plug of a 1-week pure culture of three potential antagonists and eight fungal plant pathogens, respectively. The distance between the pathogen and antagonist was $30 \mathrm{~mm}$. Each combination of pathogen/ antagonist was repeated three times, and as negative control three petri dishes were inoculated with pathogen and a water agar plug. All petri dishes were incubated at $25^{\circ} \mathrm{C}$ in the dark. The experiment was replicated three times. Radial growth of each pathogenic mycelium in dual culture was recorded by measuring colony diameter at the time when they reached the margin of the dish in controls.

\section{Light Microscope (LM)}

Dual cultures of the endophytic fungi and pathogenic fungi were carried out as described above. After 25 days, when the two fungal colonies had grown together, the morphology of the hyphae and their behavior in the contact zone were observed with a LM at magnifications of up to $400 \times$. Interactions between the fungi were photographed using a Zeiss Axioscop microscope and a digital camera (Canon Power Shot G7) or a laser confocal microscope (Zeiss LSM 510 META).

\section{Scanning Electron Microscopy (SEM)}

In order to further investigate the morphology of the hyphae and their behavior within the contact zone, samples $(2 \times 4 \mathrm{~mm})$ were cut out after 25 days. Samples were fixed for $46 \mathrm{~h}$ in $2 \%(\mathrm{v} / \mathrm{v})$ glutaraldehyde in $0.2 \mathrm{M}$ phosphate buffer ( $\mathrm{pH}$ 6.8) at room temperature. Samples were rinsed thoroughly for $12 \mathrm{~h}$ with $0.2 \mathrm{M}$ phosphate buffer ( $\mathrm{pH}$ 6.8), and then dehydrated in a graded acetone series $(30,50,70,80,90$, and $100 \%)$, each grade for $30 \mathrm{~min}$ and three times for $100 \%$ acetone. Fully dehydrated samples were dried in a critical point dryer (HCP-2, Hitachi), mounted on stubs, and then coated with gold (200 nm thickness) in a sputter coater (JFC-1600, JEOL). The coated specimens were examined with a SEM (JSM6360LV, JEOL Ltd) at $10 \mathrm{kV}$.

\section{Transmission Electron Microscopy (TEM)}

Samples were fixed in $2 \%(\mathrm{v} / \mathrm{v})$ glutaraldehyde in $0.2 \mathrm{M}$ phosphate buffer $(\mathrm{pH}$ 6.8) for $3 \mathrm{~h}$ at room temperature. 
Then samples were rinsed six times with the same buffer and post-fixed with $1 \%(\mathrm{w} / \mathrm{v})$ osmium tetroxide in the same buffer for $2 \mathrm{~h}$ at room temperature. Samples were rinsed thoroughly with $0.2 \mathrm{M}$ phosphate buffer ( $\mathrm{pH}$ 6.8), and dehydrated in a graded acetone series, each grade for $30 \mathrm{~min}$ and three times for $100 \%$ acetone. Samples were infiltrated through a series of Spurr resin in acetone, and embedded in molds with fresh $100 \%$ resin and polymerized at $65^{\circ} \mathrm{C}$ for $36 \mathrm{~h}$.

Ultrathin sections cut with a glass knife were collected on formvar coated slot grids. After drying, the grids were contrasted with uranyl acetate and lead citrate, and examined with an EM $10 \mathrm{CR}$ electron microscope (Zeiss, Oberkochen, Germany) at $60 \mathrm{kV}$. Three samples per sampling time were examined with an average of 10 grid squares per sample.

Induction of Enzymes Connected With Mycoparasitism

\section{Preparation of Fungal Cell Walls}

Similar to the method of Gao et al. [16, 18], agar discs of actively growing mycelia of $R$. solani and $P$. aphanidermatum were inoculated in Erlenmeyer flasks $(250 \mathrm{ml})$ containing $100 \mathrm{ml}$ of potato dextrose broth (PDB), respectively, and incubated on a rotary shaker of $140 \mathrm{rev} \mathrm{min}^{-1}$, at $25^{\circ} \mathrm{C}$ for 6 days. Fungal mycelia were collected by filtration through Xinhua no. 1 filter paper, and homogenized with pestle in a mortar and frozen in liquid nitrogen for several times. Cell wall preparation (CWP) was washed with $2 \% \mathrm{MgCl}_{2}$ and distilled water six times after being sonicated for $15 \mathrm{~min}$. CWP was centrifuged $(10000 \times \mathrm{g}$, $4^{\circ} \mathrm{C}, 15 \mathrm{~min}$ ), before being lyophilized and stored at $-20^{\circ} \mathrm{C}$.

\section{Culture Conditions for Enzyme Production}

A synthetic medium with colloidal chitin and sucrose as carbon sources (SMCS) was used and contained $\left(\mathrm{g} \mathrm{l}^{-1}\right.$ of distilled water) $\mathrm{NH}_{4} \mathrm{NO}_{3}, 1.0 ; \mathrm{K}_{2} \mathrm{HPO}_{4}, 0.87 ; \mathrm{KH}_{2} \mathrm{PO}_{4}$, $0.68 ; \mathrm{MgSO}_{4} \cdot 7 \mathrm{H}_{2} \mathrm{O}, 0.2 ; \mathrm{KCl}, 0.2 ; \mathrm{CaCl}_{2}, 0.2$; colloidal chitin, 2.5; saccharose, 5.0; $\quad \mathrm{FeSO}_{4} \cdot 7 \mathrm{H}_{2} \mathrm{O}, \quad 0.002$; $\mathrm{ZnSO}_{4} \cdot 7 \mathrm{H}_{2} \mathrm{O}, 0.002 ; \mathrm{MgSO}_{4} \cdot 7 \mathrm{H}_{2} \mathrm{O}, 0.002$. A basal medium (BM) was also used and contained $\left(\mathrm{g}^{-1}\right.$ of distilled water) peptone, 3.0; $\left(\mathrm{NH}_{4}\right)_{2} \mathrm{SO}_{4}, 2.0$; yeast extract, 0.5; $\mathrm{KH}_{2} \mathrm{PO}_{4}, 4.0 ; \mathrm{CaCl}_{2} \cdot 2 \mathrm{H}_{2} \mathrm{O}, 0.3 ; \mathrm{MgSO}_{4} \cdot 7 \mathrm{H}_{2} \mathrm{O}, 0.3$; Tween 20, 0.2 supplemented with 1.0 of cellulose microcrystalline (CM), or carboxymethy1 cellulose (CMC), or P. aphanidermatum cell walls, or $R$. solani cell walls, respectively. For the induction of chitinase, $\beta$-1,3-glucanases (endo- and exo-), $\beta$-glucosidases, filter paper activity (FPase), endoand exo-1,4- $\beta$-D-glucanase, aliquots $(50 \mathrm{ml})$ from the medium described above were put into $150 \mathrm{ml}$ Erlenmeyer flask and autoclaved at $121^{\circ} \mathrm{C}, 101 \mathrm{kPa}$ for $30 \mathrm{~min}$. Each flask was inoculated with five agar discs ( $5 \mathrm{~mm}$ diameter) of C. aboriginum for 4 days or S. elegans and Cylindrocarpon sp. for 6 days old PDA and incubated with shaking at $180 \mathrm{rev} \mathrm{min}^{-1}$ at $28^{\circ} \mathrm{C}$ for 6 or 10 days. Culture filtrate from each flask was collected by filtration through Xinhua no. 1 filter paper and centrifuged $(15,000 \times g)$ at $4{ }^{\circ} \mathrm{C}$ for $15 \mathrm{~min}$ and the enzymes activities were determined in the supernatants.

\section{Assays of Extracellular Enzyme Activities}

Activity of chitinase was examined by the amount of the final product of $\mathrm{N}$-acetylglucosamine (NAG) produced during the reaction. The reaction mixture consisted of $0.05 \mathrm{ml}$ of the culture filtrate, $0.05 \mathrm{ml}$ of $0.05 \mathrm{~mol}$ acetate buffer (pH 5.5), and $0.2 \mathrm{mg}$ of colloidal chitin (Calculated by dry colloidal chitin). The mixture was incubated at $40^{\circ} \mathrm{C}$ for $4 \mathrm{~h}$ and the reaction was stopped by adding $0.05 \mathrm{ml}$ of dinitrosalicylic (DNS) reagent $(0.63 \%$ DNS, $0.50 \%$ phenol, $0.50 \%$ sodium bisulphide, and $2.14 \% \mathrm{NaOH}$ ) [29] followed by heating for $5 \mathrm{~min}$. One unit (U) of chitinase activity was defined as the amount of enzyme that produced $100 \mu \mathrm{g}$ $N$-acetyl-D-glucosamine $\mathrm{h}^{-1}$ under the above conditions.

The activity of $\beta-1,3$-glucanases (endo- and exo-) was measured by mixing $0.05 \mathrm{ml}$ of the culture filtrate with

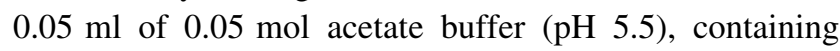
$0.1 \mathrm{mg}$ of laminarin (Sigma). The mixture was incubated at $40^{\circ} \mathrm{C}$ for $30 \mathrm{~min}$ and the reducing sugar produced was determined by the method described by Miller [29]. One unit $(\mathrm{U})$ of $\beta$-1,3-glucanase activity was defined as the amount of enzyme that produced $100 \mu \mathrm{g}$ reducing sugar $\mathrm{h}^{-1}$ under the above conditions.

Cellulases including $\beta$-glucosidases, endo-1,4- $\beta$-D-glucanase and exo-1,4- $\beta$-D-glucanase activities as well as filter paper activity (FPase) were measured by mixing $0.05 \mathrm{ml}$ of the culture filtrate with $0.05 \mathrm{ml}$ of $0.05 \mathrm{~mol}$ acetate buffer ( $\mathrm{pH} 4.8$ ) containing $0.25 \mathrm{mg}$ of salicin, CMC, $0.01 \mathrm{~g}$ of cotton and $50 \mathrm{mg}$ of Xinhua filter paper as substrates, respectively. The mixture was incubated at $50^{\circ} \mathrm{C}$ for $30 \mathrm{~min}$ ( $\beta$-glucosidases) or $60 \mathrm{~min}$ (endo- and exo-1,4- $\beta$-D-glucanases). The reaction was stopped by boiling, followed by adding $0.05 \mathrm{ml}$ of DNS reagent and incubated $5 \mathrm{~min}$ in boiling bath. One unit (U) of cellulases activity was defined as the amount of enzyme that produced $100 \mu \mathrm{g}$ reducing sugar $\min ^{-1}$ under the above conditions.

Absorbance of the supernatant was measured at $540 \mathrm{~nm}$ by a Spectramax M2 microtiter plate reader (Molecular Devices, Sunnyvale, CA).

Protein concentrations were measured using the method described by Lowry [26], using bovine serum albumin (Sigma) as standard. Absorbance of the supernatant was 
measured at $595 \mathrm{~nm}$. Specific activity was expressed in units per milligram of protein.

\section{Results}

Macroscopic Observation of Dual Cultures

Two days after inoculation, macroscopic observations revealed vigorous growth of $C$. aboriginum, S. elegans, and Cylindrocarpon sp. In the following days, mycelia of $P$. aphanidermatum and $R$. solani were overgrown by C. aboriginum which rapidly colonized the complete plate. Five days after inoculation the pink mycelium of $F$. graminearum had turned yellow in the contact zone. The white mycelium of $S$. rolfsii produced a yellow pigmentation after contact with $C$. aboriginum. No clear inhibition zone was observed. Similar results were obtained with S. elegans and Cylindrocarpon sp. 5/97-12.

Growth inhibition of all eight fungal pathogens was observed after the incubation with three endophytic fungi (Table 1). Choiromyces aboriginum had the maximum inhibitory effect on mycelial growth of $R$. solani with a reduction of $100 \%$ compared to the control, while S. elegans and Cylindrocarpon sp. were not very effective in reducing radial growth of $S$. rolfsii. Most isolates expressed mycelial growth inhibition with reductions in the range of $6070 \%$.

\section{Light Microscopic Observations}

Hyphae of the three endophytic fungi were easily recognized, because of their small diameter in comparison to the eight fungal pathogens. The endophytes tended to grow along the hyphae of the pathogen as soon as two colonies came into contact. We observed no differences between the endophytes with respect to the way they colonized the different pathogenic fungi. Hyphae of S. elegans, C. aboriginum, and Cylindrocarpon sp. coiled around hyphae of fungal pathogens and penetration was frequently observed. Here we show coils around hyphae of $R$. solani (Fig. 1a) and P. aphanidermatum (Fig. 1b) produced by C. aboriginum and hyphae of S. elegans (Fig. 1c) and Cylindrocarpon sp. (Fig. 1d) growing within hyphae of $P$. aphanidermatum.

\section{SEM and TEM Observations}

A more detailed picture of the development of coils and initiation of penetration structures was obtained by SEM and TEM experiments. Scanning electron micrographs at the contact zone revealed that hyphae of S. elegans growing along hyphae of $F$. graminearum branched frequently during coil formation (Fig. 2a). Stachybotrys elegans parasitized hyphae of $P$. aphanidermatum (Fig. 2b) and $R$. solani (Fig. 2c) in a similar way. Also C. aboriginum attached to $P$. aphanidermatum (Fig. 2d) and penetrated at the tip of a loop (arrowhead, Fig. 2d). Again, C. aboriginum parasitized hyphae of $S$. rolfsii (Fig. 2e), and hyphae of Cylindrocarpon sp. parasitized hyphae of Gaeumannomyces graminis var. tritici (Fig. 2f). Cell wall breakdown and hyphal disintegration were observed occasionally (data not shown). These SEM observations indicated that coiling of the antagonistic fungi around the pathogens was an early event preceding hyphal damage. A thorough investigation at the TEM level was essential to elucidate the nature of the antagonist pathogen interaction.

Transmission electron micrographs revealed that hyphae of $S$. elegans were closely appressed to host hyphae (Fig. 3a) and started penetrating cells of $R$. solani (Fig. 3b) or F. graminearum (Fig. 3c) by 23 days after inoculation. During penetration by the antagonist (Se), the host (Fg) produced an amorphous thickening at the site of penetration which included small dark inclusions (Fig. 3c). Four days

Table 1 Inhibition of mycelial growth of phytopathogenic fungi by three endophytic fungi isolated from reed

\begin{tabular}{lccc}
\hline Soilborne phytopathogenic fungi & \multicolumn{2}{l}{ Inhibition of mycelial growth $^{\mathrm{a}}(\%)$} & \\
\cline { 2 - 4 } & Choiromyces aboriginum & Stachybotrys elegans & Cylindrocarpon sp. \\
\hline Fusarium graminearum & $72.6 \pm 1.3$ & $83.7 \pm 0.6$ & $50.4 \pm 1.3$ \\
F. oxysporum f. sp. perniciosum & $68.2 \pm 1.3$ & $72.6 \pm 5.6$ & $61.9 \pm 0.6$ \\
F. oxysporum f. sp. vasinfectum & $68.9 \pm 3.9$ & $71.1 \pm 1.9$ & $72.6 \pm 2.1$ \\
Gaeumannomyces graminis var. tritici & $68.9 \pm 2.9$ & $77.0 \pm 1.3$ & $72.6 \pm 2.6$ \\
Pythium aphanidermatum & $40.7 \pm 3.4$ & $51.5 \pm 0.6$ & $78.5 \pm 1.3$ \\
Rhizoctonia cerealis & $55.6 \pm 3.9$ & $81.1 \pm 2.9$ & $93.3 \pm 2.2$ \\
Rhizoctonia solani & $100.0 \pm 0$ & $71.5 \pm 1.7$ & $93.3 \pm 2.2$ \\
Sclerotium rolfsii & $58.5 \pm 1.3$ & $40.1 \pm 2.5$ & $30.2 \pm 0.9$
\end{tabular}

Note: ${ }^{\text {a }}$ Mean of three replicates; Count inhibition when the time reaching the margin of the dish in Control $\mathrm{II}^{+}$. Inhibition $(\%) \quad\left(\mathrm{R}_{0}{ }^{\prime} \quad \mathrm{R}_{\mathrm{b}}\right) /$ $\mathrm{R}_{0}{ }^{\prime} \times 100$ 

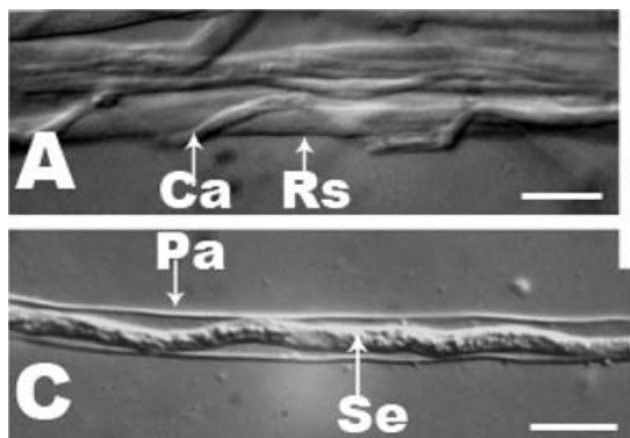

Fig. 1 Light micrographs of the hyphal interactions between three endophytic fungi and different soilborne pathogenic fungi in dual cultures. a Hypha of $C$. aboriginum (Ca) coiled around hyphae of $R$. solani (Rs). b Coiling around a hypha of $P$. aphanidermatum $(\mathrm{Pa})$ by

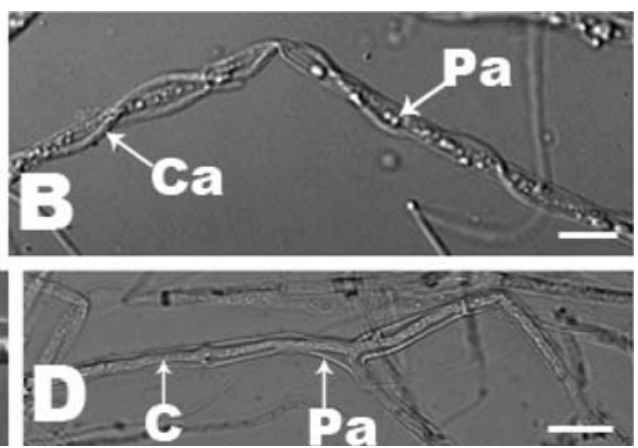

C. aboriginum (Ca). c Growth of S. elegans (Se) within a hypha of $P$. aphanidermatum (Pa). d Hyphae of Cylindrocarpon sp. (C) inside hyphal cells of $P$. aphanidermatum $(\mathrm{Pa})$
Fig. 2 Scanning electron micrographs of interactions between three endophytic fungi and different soilborne pathogenic fungi in dual cultures. a Hyphae of S. elegans (Se) growing along hyphae of $F$. graminearum $(\mathrm{Fg})$, with frequent branches and coils. b Hyphae of S. elegans (Se) growing on hyphae of $P$. aphanidermatum $(\mathrm{Pa})$. c Hyphae of $S$. elegans (Se) parasiting $R$. solani (Rs). d Penetration site of C. aboriginum $(\mathrm{Ca})$ into a hypha (arrowhead) of $P$.

aphanidermatum (Pa). e Early parasitic stages of $C$.

aboriginum $(\mathrm{Ca})$ in tight contact with a hypha of $S$. rolfsii $(\mathrm{Sr})$. f Hyphae of Cylindrocarpon sp. (C) growing on hyphae of $G$. graminis var. tritici (Ggt). Bars $5 \mu \mathrm{m}$ in (e), $7.5 \mu \mathrm{m}$ in (a d) and (f)
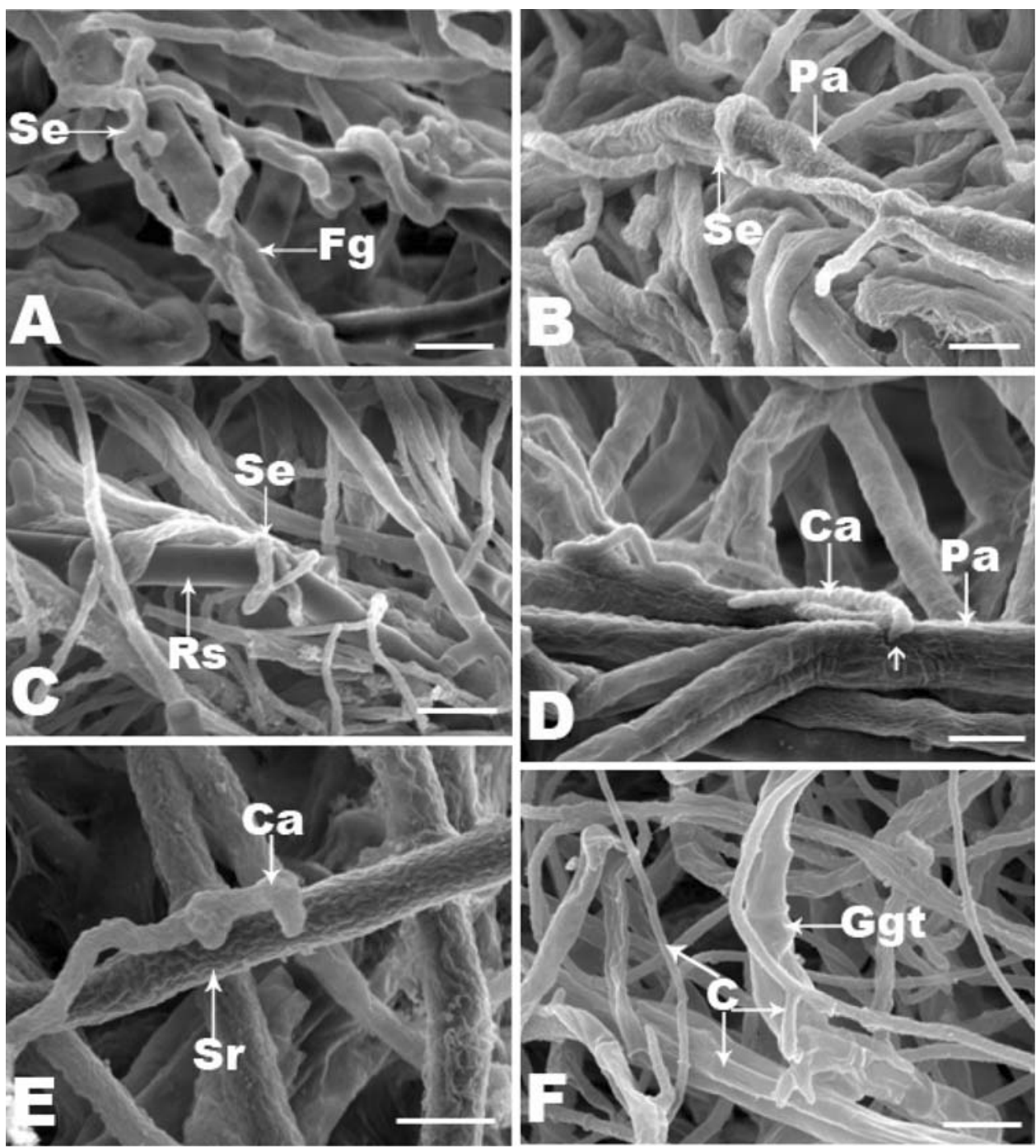

after inoculation, hyphae of $S$. elegans had entered a hypha of $S$. rolfsii which lead to retraction of the plasma membrane and serious cytoplasmic disorganization (Fig. 3d). Five days after inoculation, hyphae of $C$. aboriginum had induced cell death of $P$. aphanidermatum, and organelles were no longer discernible (Fig. 3e). Also C. aboriginum attached and coiled around hyphae of $F$. oxysporum $\mathrm{f}$. sp. perniciosum, a hemispherical wall apposition (WA) at the 
Fig. 3 Transmission electron micrographs of interactions between three endophytic fungi and different soilborne pathogenic fungi in dual cultures. a $S$. elegans (Se) appressed to a hypha of $R$. solani (Rs) 2 days after inoculation. b $S$. elegans (Se) penetrated into a hypha of $R$. solani (Rs) 3 days after inoculation. c Prominent wall apposition (WA) in a hypha of $F$. graminearum $(\mathrm{Fg})$ penetrated by $S$. elegans $(\mathrm{Se}) 3$ days after inoculation. d $S$. elegans (Se) within a hypha of $S$. rolfsii $(\mathrm{Sr})$ 4 days after inoculation. e $C$. aboriginum $(\mathrm{Ca})$ attached to a hypha of $P$. aphanidermatum (Pa) 5 days after inoculation. f C. aboriginum (Ca) attached to F. oxysporum f. sp. perniciosum (Fo) and a wall apposition (WA) at the site of contact 3 days after inoculation. $g$ Hypha of Cylindrocarpon sp. (C) penetrating into a hypha of $P$. aphanidermatum $(\mathrm{Pa}) 4$ days after inoculation.

Bars $1.5 \mu \mathrm{m}$ in (a), (b) and (d), $1 \mu \mathrm{m}$ in (c) and from (e $\mathbf{g})$
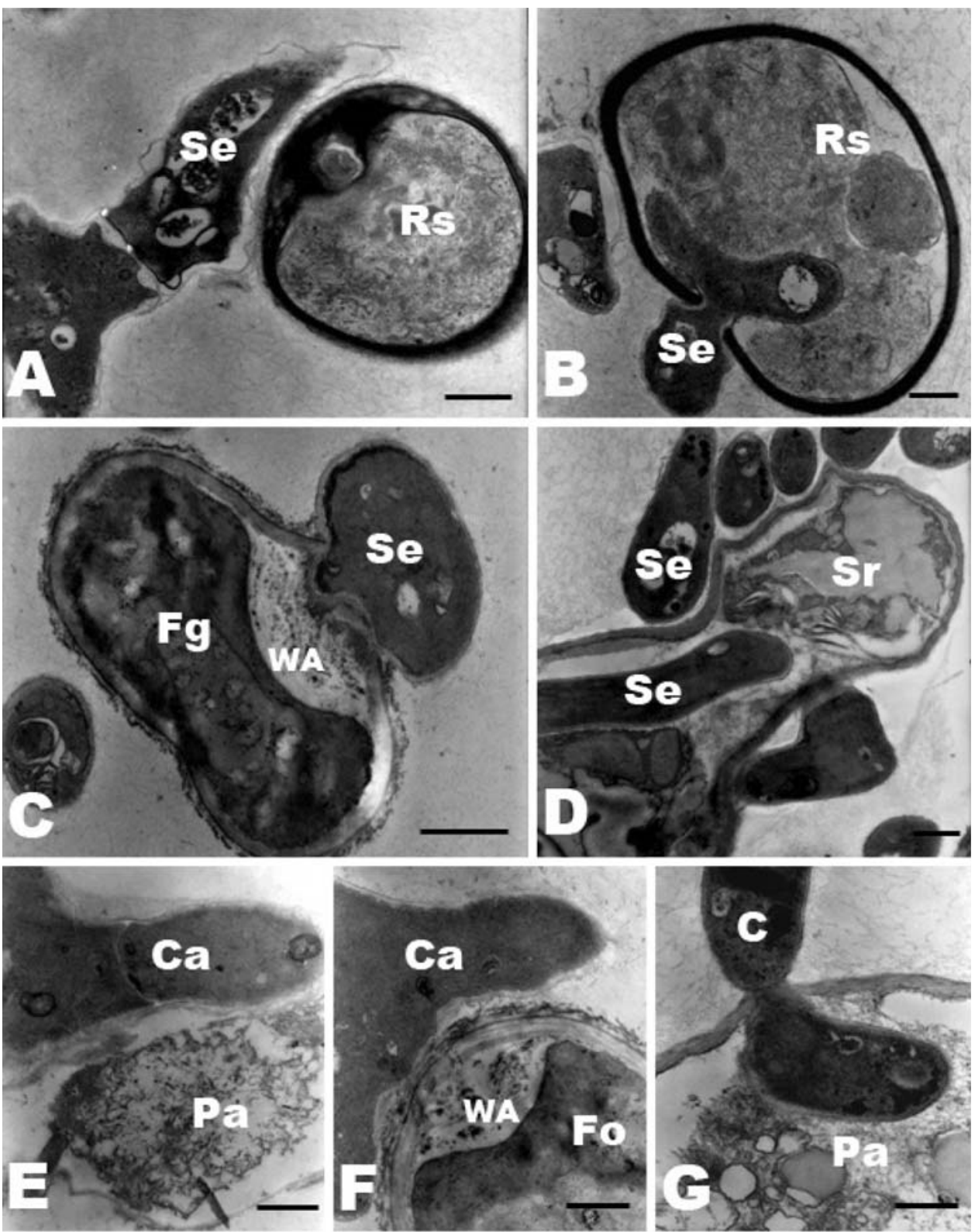

site of contact was produced (Ca) (Fig. 3f). Similarly, Cylindrocarpon sp. penetrated into a hypha of $P$. aphanidermatum around 4 days after inoculation (Fig. $3 \mathrm{~g}$ ). In summary, we found no differences in the penetration process and the way to degrade cytoplasmic contents of the pathogens by the three endophytes.

\section{Enzyme Production Related to Mycoparasitism}

The production of enzymes by the three antagonists in liquid media is listed in Table 2. Endo-1,4- $\beta$-D-glucanase (E.G., i.e., carboxymethyl cellulases, CMCase), exo-1,4- $\beta$ D-glucanase (cellobiohydrolase, $\mathrm{CBH}), \quad \beta$-glucosidases (BG) and filter paper activity (FPase), chitinases (CHI), and $\beta$-1,3-glucanase (GLU) activities were assayed by measuring the amount of reducing sugars released from suitable substrate by means of Miller's method [29].

For all three endophytes, the activities of endo-1,4- $\beta$-Dglucanase and $\beta$-glucosidases remained at a very low level in the presence of any substrate in the medium except for the synthetic medium with colloidal chitin and sucrose and the BM with carboxymethyl cellulose as a carbon source. In contrast, the $\beta-1,3$-glucanase activities were detected at a higher level.

For C. aboriginum and S. elegans, colloidal chitin was the best substrate for the induction of $\beta$-1,3-glucanases and chitinases, respectively. Specific activities were 175.61 and $213.88 \mathrm{U} \mathrm{mg}^{-1}$ for $\beta$-1,3-glucanases, 4.21 and 25.10 
Table 2 Cell wall degrading enzymes produced by fungal endophytes isolated from reed

\begin{tabular}{|c|c|c|c|c|c|c|}
\hline \multirow[t]{2}{*}{ Isolate + medium } & \multicolumn{4}{|c|}{ Cellulase activity $\left(\mathrm{U} \mathrm{mg}^{-1}\right)$} & \multirow[t]{2}{*}{$\mathrm{CHI}^{\mathrm{e}}\left(\mathrm{U} \mathrm{mg}^{-1}\right)$} & \multirow[t]{2}{*}{$\operatorname{GLU}^{\mathrm{f}}\left(\mathrm{U} \mathrm{mg}^{-1}\right)$} \\
\hline & $\mathrm{EG}^{\mathrm{a}}$ & $\mathrm{CBH}^{\mathrm{b}}$ & $\mathrm{BG}^{\mathrm{c}}$ & FPase $^{\mathrm{d}}$ & & \\
\hline C. aboriginum + Basal & $0.16 \pm 0.02$ & $0.54 \pm 0.03$ & $0.09 \pm 0.01$ & $0.69 \pm 0.04$ & $1.89 \pm 0.29$ & $157.48 \pm 1.68$ \\
\hline +Basal + CMC $^{\mathrm{g}}$ & $0.15 \pm 0.04$ & $0.79 \pm 0.13$ & $0.04 \pm 0.01$ & $0.69 \pm 0.04$ & $1.57 \pm 0.01$ & $52.85 \pm 0.93$ \\
\hline+ Basal $+\mathrm{CM}^{\mathrm{h}}$ & $0.14 \pm 0.03$ & $0.43 \pm 0.11$ & $0.15 \pm 0.02$ & $0.42 \pm 0.08$ & $1.66 \pm 0.25$ & $120.37 \pm 1.80$ \\
\hline+ Basal + $\mathrm{Rs}^{\mathrm{i}}$ & $0.14 \pm 0.01$ & $0.58 \pm 0.04$ & $0.70 \pm 0.01$ & $0.54 \pm 0.03$ & $3.65 \pm 0.27$ & $133.42 \pm 3.97$ \\
\hline+ Basal $+\mathrm{Pa}^{\mathrm{j}}$ & $0.22 \pm 0.01$ & $0.90 \pm 0.01$ & $0.26 \pm 0.07$ & $0.82 \pm 0.05$ & $1.87 \pm 0.02$ & $98.25 \pm 4.66$ \\
\hline$+\mathrm{SMCS}^{\mathrm{k}}$ & $0.13 \pm 0.06$ & $0.69 \pm 0.01$ & $0.14 \pm 0.02$ & $0.97 \pm 0.06$ & $4.21 \pm 0.36$ & $175.61 \pm 5.30$ \\
\hline S. elegans + Basal & $0.15 \pm 0.13$ & $3.43 \pm 0.10$ & $0.11 \pm 0.00$ & $1.70 \pm 0.09$ & $1.85 \pm 0.13$ & $11.60 \pm 1.27$ \\
\hline +Basal + $\mathrm{CMC}^{\mathrm{g}}$ & $0.37 \pm 0.03$ & $2.93 \pm 0.03$ & $1.32 \pm 0.00$ & $1.45 \pm 0.14$ & $1.65 \pm 0.11$ & $29.64 \pm 0.81$ \\
\hline+ Basal $+\mathrm{CM}^{\mathrm{h}}$ & $0.26 \pm 0.02$ & $1.34 \pm 0.16$ & $0.12 \pm 0.02$ & $1.23 \pm 0.03$ & $1.62 \pm 0.02$ & $12.04 \pm 1.52$ \\
\hline+ Basal + $\mathrm{Rs}^{\mathrm{i}}$ & $0.26 \pm 0.02$ & $3.19 \pm 0.16$ & $0.43 \pm 0.04$ & $1.23 \pm 0.03$ & $2.61 \pm 0.22$ & $112.85 \pm 3.70$ \\
\hline+ Basal $+\mathrm{Pa}^{\mathrm{j}}$ & $0.38 \pm 0.04$ & $1.67 \pm 0.01$ & $0.63 \pm 0.11$ & $1.30 \pm 0.07$ & $1.12 \pm 0.03$ & $33.01 \pm 4.21$ \\
\hline$+\mathrm{SMCS}^{\mathrm{k}}$ & $4.27 \pm 1.84$ & $4.04 \pm 0.76$ & $4.86 \pm 0.30$ & $1.61 \pm 0.05$ & $25.10 \pm 2.79$ & $213.88 \pm 18.79$ \\
\hline Cylindrocarpon sp. + Basal & $0.38 \pm 0.00$ & $3.77 \pm 0.10$ & $0.34 \pm 0.00$ & $1.68 \pm 0.01$ & $2.23 \pm 0.03$ & $11.41 \pm 2.56$ \\
\hline+ Basal $+\mathrm{CMC}^{\mathrm{g}}$ & $0.40 \pm 0.06$ & $3.34 \pm 0.11$ & $0.67 \pm 0.05$ & $2.38 \pm 0.08$ & $1.80 \pm 0.09$ & $26.79 \pm 0.73$ \\
\hline+ Basal $+\mathrm{CM}^{\mathrm{h}}$ & $0.19 \pm 0.01$ & $3.09 \pm 0.10$ & $0.17 \pm 0.00$ & $1.88 \pm 0.10$ & $1.85 \pm 0.13$ & $8.78 \pm 2.03$ \\
\hline+ Basal $+\mathrm{Rs}^{\mathrm{i}}$ & $0.30 \pm 0.02$ & $3.46 \pm 0.15$ & $0.26 \pm 0.00$ & $2.32 \pm 0.12$ & $1.96 \pm 0.14$ & $18.4 \pm 0.85$ \\
\hline+ Basal $+\mathrm{Pa}^{\mathrm{j}}$ & $0.42 \pm 0.08$ & $2.93 \pm 0.05$ & $0.20 \pm 0.10$ & $1.95 \pm 0.10$ & $1.68 \pm 0.13$ & $21.89 \pm 2.86$ \\
\hline$+\mathrm{SMCS}^{\mathrm{k}}$ & $0.17 \pm 0.00$ & $3.32 \pm 0.16$ & $0.24 \pm 0.01$ & $1.46 \pm 0.04$ & $1.89 \pm 0.04$ & $8.63 \pm 1.62$ \\
\hline
\end{tabular}

Notes: ${ }^{\mathrm{a}}$ Endo $1,4 \beta$ D glucanase; ${ }^{\mathrm{b}}$ exo $1,4 \beta$ D glucanase; ${ }^{\mathrm{c}} \beta$ Glucosidases; ${ }^{\mathrm{d}}$ Filter paper activity; ${ }^{\mathrm{e}}$ Chitinase; ${ }^{\mathrm{f}} \beta$-1,3-glucanases; ${ }^{\mathrm{g}}$ carbo xymethy 1 cellulose; ${ }^{\mathrm{h}}$ cellulose microcrystalline; ${ }^{\mathrm{i}}$ Preparation of hyphal cell walls from Rhizoctonia solani; ${ }^{\mathrm{j}}$ Preparation of hyphal cell walls from Pythium aphanidermatum; and ${ }^{\mathrm{k}}$ A synthetic medium with colloidal chitin and sucrose as carbon sources

$\mathrm{U} \mathrm{mg}^{-1}$ for chitinases. Fungal cell walls from $R$. solani were also superior carbon sources for the induction of $\beta$ 1,3-glucanases and chitinases. Similar results by Archambault et al. [1], had shown that $\beta$-1,3-glucanases are produced during the interaction between the mycoparasite $S$. elegans and its host $R$. solani.

For Cylindrocarpon sp., high activities of $\beta$-1,3-glucanases were detected in the presence of carboxymethyl cellulose or fungal cell walls from $P$. aphanidermatum in the BM. Also, the activities of exo-1,4- $\beta$-D-glucanase $(\mathrm{CBH})$ and filter paper activity (FPase) were somewhat higher than that of $\beta$-glucosidases (BG) and endo-1,4- $\beta$-Dglucanase (E.G.). This result suggested that Cylindrocarpon sp. has a strong ability to degrade the cellulose in cell wall of an oomycete such as P. aphanidermatum.

\section{Discussion}

The selection of effective antagonistic organisms is the first and foremost step in biological control. Most studies on antagonism have focused on a few model biocontrol strains only such as Trichoderma spp. [7, 8, 19], Pythium oligandrum [28], and Penicillium oxalicum [11]. Very few reports exist for S. elegans as biocontrol agents [1, 34]. Our investigations have provided the first evidence that mycoparasitism of endophytic $C$. aboriginum, S. elegans, and Cylindrocarpon sp. isolated from common reed contribute to antagonistic activities of endophytic fungi toward soilborne phytopathogenic fungi.

Fungal interactions in co-culture showed that $C$. $a b$ originum, S. elegans, and Cylindrocarpon sp inhibited mycelial growth of several soilborne phytopathogenic fungi. A similar coiling around or penetrating into the hyphae of these pathogenic fungi was confirmed through LM, SEM and TEM observations.

Our experiments on the mechanism behind this mode of parasitism show that $C$. aboriginum and S. elegans produce enzymes capable of degrading chitin and, $\beta$-1,3-glucan, two major cell wall compounds of many pathogenic fungi except for oomycetous fungi. In the presence of chitin or $R$. solani cell wall fragments, $C$. aboriginum, and $S$. elegans produced significant amounts of both chitinases and $\beta$-1,3-glucanases. These lytic enzymes, which are key enzymes in the lysis of cell walls of higher fungi, are produced by other organisms that are known to attack and parasitize fungi [14 16, 27, 30]. Media containing chitin or fungal cell wall fragments as carbon source supported high production of chitinases and $\beta$-1,3-glucanases, respectively. Similarly, Tweddell et al. [35] showed that the production of these enzymes in S. elegans is favored by chitin and fungal cell wall fragments. In addition, our study 
shows that the production of $\beta$-1,3-glucanases was much higher than that of chitinases in medium containing chitin or cell wall fragments, as well as other carbon sources. These results may suggest that $\beta$-1,3-glucanases could be more important than chitinases in the degradation of $R$. solani cell walls. This is not surprising since cell walls of $R$. solani are known to contain significantly more $\beta-1,3-$ glucan polymers than chitin [20]. In contrast to $C . a b$ originum and $S$. elegans, Cylindrocarpon sp. produced lower amounts of $\beta-1,3$-glucanases in the presence of chitin, fungal cell wall fragments.

On the other hand, $C$. aboriginum produced higher activity of $\beta$-1,3-glucanases in BM without any carbon source. This result may imply autolysis occurred under conditions of carbon energy source exhaustion. Therefore, starvation could also induce the $\beta$-1,3-glucanase. This is similar to results with the biocontrol agent Chaetomium spirale ND35 [16].

For cellulase including endo-1,4- $\beta$-D-glucanase (E.G., i.e., carboxymethyl cellulases, CMCase), exo-1,4- $\beta$-D-glucanase (cellobiohydrolase, $\mathrm{CBH}$ ), $\beta$-glucosidases (BG), and filter paper activity (FPase), no correlation was found between production of enzymes from $C$. aboriginum and any substrate as a carbon source in the medium. We found that the activities of exo-1,4- $\beta$-D-glucanase and filter paper activity produced by $S$. elegans and Cylindrocarpon sp. were detected at a higher level in the presence of any substrates as a carbon source in the medium. This may suggest that production of exo-1,4- $\beta$-D-glucanase and filter paper activity by Cylindrocarpon sp. does not rely on any substrate as a carbon source in the medium. But, to some extent, production of exo-1,4- $\beta$-D-glucanase by $S$. elegans depends upon several substrates such as colloidal chitin and sucrose in the synthetic medium and $R$. solani cell wall fragments or without any carbon source in the BM.

It appears to be that no correlation was found between production of enzymes and degradability of cellulose. But, surely we observed that the endophytic fungi isolated from reed were able to penetrate and colonize the $P$. aphanidermatum hypha as seen with light and electron microscope. This may be the result of synergism of cellulases, chitinases, and $\beta$-1,3-glucanases because oomycetous fungal cell walls primarily contain cellulose, glucans (primarily $\beta-1,4-$; $\beta-1,3-; \beta-1,6-;$ and $\alpha-1,3$-glucans) and trace amounts of chitin as well.

In recent years, some genes encoding for CWDEs have been cloned and expressed in beneficial fungi to promote enzyme secretion, with the purpose to improve control. For example, transformants of $T$. harzianum that overexpressed a $33 \mathrm{kDa}$ chitinase gene showed up to 200 -fold greater activity and were more effective than the wild type by inhibiting the growth of the fungal pathogen $R$. solani [24]. Also transformants of $T$. virens in which $\beta-1,3-$ and $\beta-1,6-$ glucanase genes were upregulated displayed much higher levels of enzyme activity than the wild-type [12]. Recent genetic evidence suggested that a $42 \mathrm{kDa}$ extracellular chitinase produced by several Trichoderma species has a critical role in antagonism against Botrytis cinerea and $R$. solani $[3,22,23,25]$ and is combined with improved biocontrol efficacy [9].

SEM and TEM investigations of hyphal penetration of soilborne pathogenic fungi by three fungal antagonists suggest that extracellular metabolites such as CWDEs could be responsible for the observed penetration and degradation. The present ultrastructural investigation together with biochemical data on CWDEs activity indicate that production of these enzymes may be of great significance in the antagonistic process. Our electron micrographs support enzymatic penetration of the host hyphae and this observation supports the biochemical and molecular data on the role of enzymes in mycoparasitism.

Acknowledgments This work was supported by the Deutsche Forschungsgemeinschaft (DFG) through the Collaborative Research Center 454 (Littoral Zone of Lake Constance) and the National Natural Science Foundation of China (30710103021, 30571498, and 30872024) as well as Foundation of Shaanxi Key Laboratory of Molecular Biology for Agriculture, Northwest A \& F University (200701).

\section{References}

1. Archambault C, Coloccia C, Kermasha S, Jabaji Hare SH (1998) Characterization of an endo 1,3 $\beta$ D glucanase produced during the interaction between the mycoparasite Stachybotrys elegans and its host Rhizoctonia solani. Can J Microbiol 44:989 997

2. Askary H, Benhamou N, Brodeur J (1997) Ultrastructural and cytochemical investigations of the antagonistic effect of Verti cillium lecanii on cucumber powdery mildew. Phytopathology 87:359 368

3. Baek JM, Howell CR, Kenerley CM (1999) The role of extra cellular chitinase from Trichoderma virens Gv29 8 in the bio control of Rhizoctonia solani. Curr Genet 35:41 45

4. Benhamou N, Garand C, Goulet A (2002) Ability of nonpatho genic Fusarium oxysporum strain Fo47 to induce resistance against Pythium ultimum infection in cucumber. Appl Environ Microbiol 65:4044 4060

5. Benyagoub M, Jabaji Hare SH, Banville G, Charest PM (1994) Stachybotrys elegans: a destructive mycoparasite of Rhizoctonia solani. Mycol Res 98:493 505

6. Benyagoub M, Jabaji Hare SH, Chamberland H, Charest PM (1996) Cytochemical and immunocytochemical investigation of the mycoparasitic interaction between Stachybotrys elegans and its host Rhizoctonia solani (AG 3). Mycol Res 100:79 86

7. Bhuyan SA (1994) Antagonistic effective of Trichoderma viride, T. harzianum and Asperigillus terreuson, Rhizoctonia solani causing sheath blight of rice. J Agric Sci Soc North East Ind $7: 125 \quad 127$

8. Campanile G, Ruscelli A, Luisi N (2007) Antagonistic activity of endophytic fungi towards Diplodia corticola assessed by in vitro and in planta tests. Eur J Plant Pathol 117:237 246

9. Carsolio C, Benhamou N, Haran S, Cortes C, Gutierrez A, Chet I, Herrera Estrella A (1999) Role of the Trichoderma harzianum 
endochitinase gene, ech42, in mycoparasitism. Appl Environ Microbiol 65:929 935

10. Chernin L, Chet I (2002) Microbial enzymes in the biocontrol of plant pathogens and pests. In: Dick RP, Burns RG (eds) Enzyme in the environment. Marcel Dekker, New York, pp 171225

11. De Cal A, Pascual S, Larena I, Melgarejo P (1995) Biological control of Fusarium oxysporum f. sp. lycopersici. Plant Pathol 44:909 917

12. Djonovic S, Vittone G, Mendoza Herrera A, Kenerley CM (2007) Enhanced biocontrol activity of Trichoderma virens transfor mants constitutively coexpressing $\beta 1,3$ and $\beta 1,6$ glucanase genes. Mol Plant Pathol 8:469 480

13. El Ghaouth A, Wilson CL, Wisniewski M (1998) Ultrastructural and cytochemical aspects of the biological control of Botrytis cinerea by Candida saitoana in apple fruit. Phytopathology 88:282 291

14. Elad Y, Chet I, Henis Y (1982) Degradation of plant pathogenic fungi by Trichoderma harzianum. Can J Microbiol 28:719 725

15. Elad Y, Lifshitz R, Baker R (1985) Enzymatic activity of the mycoparasite Pythium nunn during interaction with host and non host fungi. Physiol Plant Pathol 27:131 148

16. Gao K, Liu X, Friesem D, Chernin L, Shi C (2005) Cell wall degrading enzymes involved in mycoparasitism of the biocontrol agent Chaetomium spirale ND35. Sci Silvae Sinicae 41:205 210

17. Gao K, Liu X, Kang Z, Mendgen K (2005) Mycoparasitism of Rhizoctonia solani by endophytic Chaetomium spirale ND35: ultrastructure and cytochemistry of the interaction. J Phytopathol 153:280 290

18. Gao KX, Pang YD, Qin NH, Liu XG, Kang ZS (2006) Synergistic antifungal activity of antibiotics and hydrolytic enzymes from endophytic Chaetomium spirale ND35. Acta Phytopathol Sin 36:347 358

19. Gong G, Zhang H, Zeng G, Jiang S (1998) Studies on modes of antagonism for Trichoderma longibrachiatum Riaia against Botrytis cinerea. J Yunnan Agric Univ 13:93 96

20. Hadar Y, Chet I, Henis Y (1979) Biological control of Rhizoc tonia solani damping off with wheat bran culture of Trichoderma harzianum. Phytopathology 69:64 68

21. Hubbard JP, Harman GE, Eckenrode CJ (1982) Interaction of a biological agent, Chaetomium globosom, with seed coat micro flora. Can J Microbiol 28:431 437

22. Kim DJ, Baek JM, Uribe P, Kenerley CM, Cook DR (2002) Cloning and characterization of multiple glycosyl hydrolase genes from Trichoderma virens. Curr Genet 40:374 384

23. Kubicek CP, Mach RL, Peterbauer CK, Lorito M (2001) Trich oderma: from genes to biocontrol. J Plant Pathol 83:11 24

24. Limon MC, Pintor Toro JA, Benitez T (1999) Increased anti fungal activity of Trichoderma harzianum transformants that overexpress a $33 \mathrm{kDa}$ chitinase. Phytopathology 89:254 261
25. Lorito M, Woo SL, Garcia I, Colucci G, Harman GE, Pintor Toro JA, Filippone E, Muccifora S, Lawrence CB, Zoina A, Tuzun S, Scala F, Fernandez IG (1998) Genes from mycoparasitic fungi as a source for improving plant resistance to fungal pathogens. Proc Natl Acad Sci USA 95:7860 7865

26. Lowry OH, Rosebrough NJ, Farr AL, Randall RJ (1951) Protein measurement with the folin phenol reagent. J Biol Chem 193:265 275

27. McQuilken MP, Gemmell J (2004) Enzyme production by the mycoparasite Verticillium biguttatum against Rhizoctonia solani. Mycopathologia 157:201 205

28. Mette MA, Eigil N (1999) Interactions between the mycoparasite Pythium oligandrum and sclerotia of the plant pathogen Scle rotinia sclerotiorum. Euro J Plant Pathol 105:761 768

29. Miller GL (1959) Use of dinitrosalicylic reagent for determina tion of reducing sugars. Anal Biochem 31:426 428

30. Mucha J, Dahm H, Strzelczyk E, Werner A (2006) Synthesis of enzymes connected with mycoparasitism by ectomycorrhizal fungi. Arch Microbiol 185:69 77

31. Neubert K, Mendgen K, Brinkann H, Wirsel SGR (2006) Only a few fungal species dominate highly diverse mycofloras associated with the common reed. Appl Environ Microbiol 72:1118 1128

32. Picard K, Tirilly Y, Benhamou N (2000) Cytological effects of cellulases in the parasitism of Phytophthora parasitica by Pyth ium oligandrum. Appl Environ Microbiol 66:4305 4314

33. Sivan A, Elad Y, Chet I (1984) Biological control effects of a new isolate of Trichoderma harzianum on Pythium aphanider matum. Phytopathology 74:498 501

34. Taylor G, Jabaji Hare SH, Charest PM, Khan W (2002) Purifi cation and characterization of an extracellular exochitinase, $\beta N$ acetylhexosaminidase, from the fungal mycoparasite Stachybot rys elegans. Can J Microbiol 48:311 319

35. Tweddell RJ, Jabaji hare SH, Charest PM (1994) Production of chitinases and $\beta 1,3$ glucanases by Stachybotrys elegans, a my coparasite of Rhizoctonia solani. Appl Environ Microbiol 60:489 495

36. Tweddell RJ, Marchall J, Jabaji hare SH (1996) Endo 1,3 $\beta$ glucanase production by Stachybotrys elegans, a mycoparasite of Rhizoctonia solani. Mycologia 88:410 415

37. Vázquez Garciduenas S, Leal Morales CA, Herrera Estrella A (1998) Analysis of the $\beta 1,3$ glucanolytic system of the biocon trol agent Trichoderma harzianum. Appl Environ Microbiol 64:1442 1446

38. Weinding R (1932) Trichoderma lingorum as a parasite of other soil fungus. Phytopathology 22:837 845

39. Wirsel SGR, Leibinger W, Ernst M, Mendgen K (2001) Genetic diversity of fungi closely associated with common reed. New Phytol 149:589 598 